\title{
DERYWATY POGODOWE JAKO INSTRUMENT ZARZĄDZANIA RYZYKIEM POGODOWYM
}

\section{WPROWADZENIE}

Podmiotom funkcjonującym w dzisiejszych realiach gospodarczych towarzyszy szereg rodzajów ryzyka. Źródła ryzyka znajduja się zarówno w otoczeniu wewnętrznym, jak i zewnętrznym przedsiębiorstwa. Aby neutralizować negatywne skutki finansowe realizacji ryzyka - przedsiębiorstwa podejmuja próby zarządzania nim.

Jednym z rodzajów ryzyka, które wpływa na znaczną liczbę funkcjonujących przedsiębiorstw, jest ryzyko pogodowe. Zmienność otaczających czynników atmosferycznych może wpływać na rozmiary prowadzonej działalności (np. temperatura ma wpływ na wielkość sprzedaży napojów chłodzących) albo też uniemożliwiać w ogóle jej prowadzenie (np. działalność przedsiębiorstwa zajmujacego się odśnieżaniem dachów w przypadku braku opadów śniegu jest bezcelowa). W zależności od rodzaju prowadzonej działalności pogoda może mieć mniejszy lub większy wpływ na funkcjonowanie jednostki, czy to przez zmniejszenie wielkości przychodów, czy też zwiększenie wielkości kosztów. Nie można pominać jednak strat materialnych wywołanych przez czynniki pogodowe. Aktywa przedsiębiorstwa mogą ulec zniszczeniu (np. silny wiatr może spowodować uszkodzenia pokrycia dachowego, uderzenie pioruna może doprowadzić do pożaru budynku), ale także pogoda może mieć wpływ na jakość produktów przedsiębiorstwa (np. zbyt duża wilgotność powietrza nie sprzyja przechowywaniu niektórych wyrobów, przez co te mogą się psuć - głównie płody rolne). W przypadku strat materialnych znajduja zastosowanie tradycyjne ubezpieczenia; z kolei ubezpieczenia indeksowe moga być zastosowane tam, gdzie pogoda wpływa na chociażby wielkość przychodów jednostki (za przykład mogą tu posłużyć chociażby indeksowe ubezpieczenia suszy stosowane w Stanach Zjednoczonych). Według różnych szacunków ok. 70\% światowej działalności gospodarczej jest narażone na zmienność warunków atmosferycznych $^{1}$.

${ }^{1}$ K. Burnecki, G. Kukla, Instrumenty finansowe a ryzyko pogodowe, „Asekuracja\&Re” 2001, nr 10(57), s. 26. 
Powstaje zatem problem zabezpieczenia się przedsiębiorstw przed wpływem pogody na rezultaty ich działalności. Obecnie rynek finansowy i kapitałowy (w zależności od okresu zabezpieczenia przed skutkami ryzyka) proponuje podmiotom dwie podstawowe formy transferu finansowych skutków realizacji ryzyka pogodowego. $\mathrm{Z}$ jednej strony podmioty mogą zawrzeć umowę ubezpieczenia, z drugiej zaś - oferowane są im instrumenty pochodne ${ }^{2}$. Trzecią droga zabezpieczenia się przed skutkami ryzyka pogodowego może być także zmiana lokalizacji prowadzenia działalności czy też posiadanie oddziałów w różnych regionach geograficznych (dywersyfikacja ryzyka pogodowego dla jednostki). Warto w tym miejscu wspomnieć także o znaczeniu rozwoju inżynierii budowlanej na rozmiary ryzyka pogodowego przedsiębiorstw. Doskonałym, funkcjonującym już przykładem jest technika budowlana neutralizująca drgania powierzchni ziemi stosowana w Japonii.

W artykule podjęto próbę klasyfikacji podmiotów ze względu na skalę oddziaływania pogody na wielkość przychodów lub kosztów przedsiębiorstwa, które mogłyby w ramach procesu zarządzania ryzykiem pogodowym wykorzystać instrumenty pochodne, a szczególnie opcje pogodowe. Na wstępie przedstawiono istotę ryzyka pogodowego, formułując jego definicję oraz klasyfikując to zjawisko. Następnie dokonano wyszczególnienia tych podmiotów, na które pogoda ma wyraźny wpływa. Dalej zaprezentowano opcję pogodowa, zaczynając od wybranych elementów konstrukcji tego instrumentu, poprzez historię jego funkcjonowania na rynku światowym, a kończąc na refleksjach na temat możliwości zastosowania opcji pogodowych w polskich realiach

\section{CHARAKTERYSTYKA RYZYKA POGODOWEGO}

Ryzyko pogodowe jest rozumiane jako negatywny wpływ wahania czynników pogodowych na działalność przedsiębiorstwa. Czynniki te od zawsze miały wpływ na działalność podejmowaną przez człowieka. Dziś jednak w wyniku m.in. efektu cieplarnianego wahania warunków pogodowych zyskały na znaczeniu ze względu na ich przyśspieszony i wzmocniony charakter ${ }^{3}$. Warto zaznaczyć, że część naukowców uważa, że nie istnieje takie zjawisko, jak efekt cieplarniany. Emisja przez człowieka dwutlenku węgla nie ma żadnego znaczenia, gdyż klimat zmienia się z przyczyn naturalnych od tysięcy lat.

Ryzyko pogodowe wynika ze zmienności warunków atmosferycznych porównywanych dla tego samego miejsca w kolejnych odcinkach czasu. Zmienność ta jest rozumiana jako odchylenie mierzonych czynników pogodowych od

\footnotetext{
${ }^{2}$ J. Pawłowski, Zarzadzanie ryzykiem pogodowym - przykład wykorzystania pogodowego instrumentu pochodnego przez producenta piwa $w$ Polsce, w: K. Jajuga W. Ronka-Chmielowiec (red.), Inwestycje finansowe $i$ ubezpieczenia - tendencje światowe a rynek polski, Wyd. UE we Wrocławiu, Wrocław 2014, s. 255-256.

${ }^{3}$ D. Blachowski, Ryzyko pogodowe $i$ pogodowe instrumenty pochodne $w$ przedsiębiorstwach energetycznych, „Zeszyty Naukowe Uniwersytetu Szczecińskiego” nr 640, Finanse, Rynki Finansowe, Ubezpieczenia nr 38, Szczecin 2011, s. 639-640.
} 
ich średniej wieloletniej. Jako przykład może posłużyć temperatura w centrum Poznania 1 stycznia - każdego roku jej wartość jest różna. Gdyby możliwe było dokładne prognozowanie pogody w długim okresie, zakres oddziaływania ryzyka pogodowego zostałby znacznie ograniczony. Pomimo rozwoju meteorologii dziś wciąż możliwe jest wiarygodne prognozowanie pogody w okresie nie dłuższym niż w horyzoncie kilku dni (im dłuższy bowiem jest horyzont czasowy prognozy, tym dokładność prognozy jest niższa). Z punktu widzenia zarządzania ryzykiem pogodowym w przedsiębiorstwach jest to zdecydowanie zbyt krótki okres ${ }^{4}$.

Ryzyko pogodowe, ze względu na jego wpływ na otoczenie, dzieli się na dwie grupy:

- ryzyko o charakterze katastroficznym,

- ryzyko o charakterze niekatastroficznym ${ }^{5}$.

Ryzyko o charakterze katastroficznym występuje w wyniku takich zjawisk, jak chociażby: trzęsienie ziemi, huragan, tornado, powódź, deszcz nawalny, gradobicie, burze i zamiecie śnieżne czy ekstremalnie wysokie temperatury. Realizacja tego ryzyka niesie za sobą bardzo dużą skalę zniszczeń, która jednocześnie dotyka wiele podmiotów, bez względu na to, czy są to przedsiębiorstwa czy też gospodarstwa domowe.

W przypadku ryzyka pogodowego o charakterze niekatastroficznym jego istota polega na odchyleniu warunków pogodowych od ich średniego, normalnego stanu. Skala występujacych odchyleń nie jest jednak tak znacząca, jak w przypadku zjawisk katastroficznych. Przejawia się ono zazwyczaj jako okres występowania ponadprzeciętnych lub niedostatecznych opadów deszczu czy śniegu, wzmożonego ciepła lub zimna czy też większej ilości dni wietrznych lub bezwietrznych. Takie zjawiska występuja praktycznie codziennie w różnych regionach świata, różnią się zaś intensywnością oraz skalą oddziaływania na podmioty. Jednorazowy wpływ na otoczenie jest w tym przypadku dużo mniejszy niż w przypadku ryzyka katastroficznego, jednak łączny wpływ na otoczenie, mierzony w dłuższym okresie, jest godny uwagi ${ }^{6}$. Zazwyczaj w literaturze to właśnie ryzyko pogodowe o charakterze niekatastroficznym jest rozumiane jako „ryzyko pogodowe”, taka też terminologia została przyjęta w tym artykule.

Ryzyko pogodowe ze względu na charakter zjawiska pogodowego dzieli się na kilka kategorii. Pewne grupy podmiotów są wrażliwe na jedne czynniki pogodowe, a na inne nie. Na przykład o ile temperatura ma znaczny wpływ na funkcjonowanie sektora energetycznego, o tyle poziom wilgotności powietrza w zasadzie nie jest w tym sektorze istotny. Właśnie ze względu na rodzaj

${ }^{4}$ G. Michalski, J. Kupczyk, Wptyw ryzyka pogodowego na finansowa efektywność przedsiębiorstwa, https://michalskig.wordpress.com/2011/11/12/weather-risk-and-firm-value-maximization-wplyw-ryzyka-pogodowe-go-na-finansowa-efektywnosc-przedsiebiorstwa/, 2011, s. 3 [dostęp: 15.12.2015].

${ }^{5}$ D. Michalak, Derywaty pogodowe jako instrument efektywnego zarzadzania ryzykiem pogodowym, „Acta Innovations” 2011, nr 1, s. 42.

${ }^{6} \mathrm{~J}$. Pawłowski, Indeksy meteorologiczne a pogodowe instrumenty pochodne, w: G. Borys, A. Janusz (red.), Rola instytucji i rynku finansowego w świetle celów i zasad zrównoważonego rozwoju, Wyd. UE we Wrocławiu, Wrocław 2013, s. 193-194. 
czynnika atmosferycznego konstruowane są instrumenty mające zabezpieczać przed dana kategoria ryzyka pogodowego. Podstawowe kategorie ryzyka pogodowego ze względu na charakter zjawiska pogodowego przedstawiono na schemacie 1.

\section{Schemat 1}

Podstawowe rodzaje ryzyka pogodowego

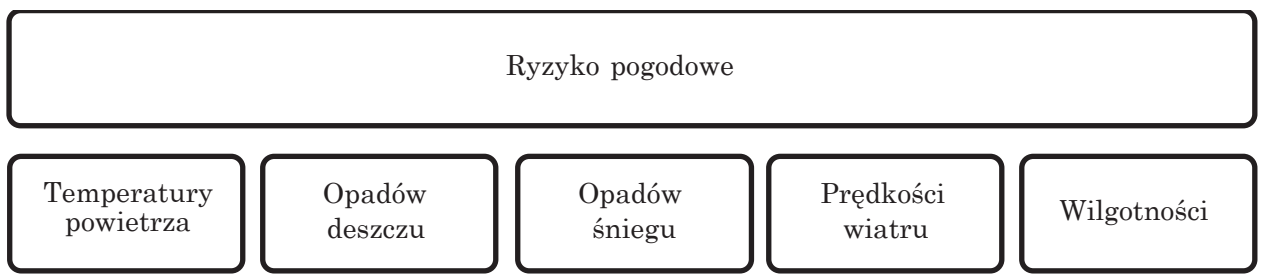

Źródło: J. Preś, Zarzqdzanie ryzykiem pogodowym, CeDeWu, Warszawa 2007, s. 113-114.

Ekspozycja na ryzyko pogodowe wpływa na dochodowość przedsiębiorstwa. Może dotyczyć to zarówno wielkości produkcji, zdolności wytwórczych, wielkości sprzedaży, jak i ceny sprzedaży?

Ryzyko pogodowe posiada specyficzne dla siebie cechy. Jedna z nich jest brak występowania, jak dotychczas, instrumentów kasowych, mogących chronić podmioty przed skutkami realizacji tego ryzyka. Nie oznacza to, że w przyszłości instrumenty kasowe nie mogłyby znaleźć zastosowania. W praktyce obecnie podmioty, które chciałyby zabezpieczyć się przed tym ryzykiem, moga skorzystać z ubezpieczeń indeksowych lub też z oferowanych przez rynek instrumentów pochodnych. Innymi cechami ryzyka pogodowego sa:

- lokalny charakter - zjawiska pogodowe występują w określonym zakresie geograficznym (np. deszcze zenitalne na obszarze równikowym);

- sezonowość - zjawiska pogodowe sa zmienne w czasie; typowym przykładem jest występowanie pór roku. Nie oznacza to jednak, że w ramach danych pór roku zjawiska pogodowe sa przewidywalne, a jedynie, że występuja pewne cechy właściwe dla danego okresu. Przykładowo mróz występuje zima, ale nie jest znana ani jego siła, ani dokładny okres jego wystapienia;

- występowanie tzw. grubych ogonów - są to zjawiska charakteryzujące się niskim prawdopodobieństwem, ale ich wystapienie niesie za sobą wysokie straty;

- trudność przeliczania skutków zjawisk atmosferycznych na wielkości pieniężne;

- zmienność skutków zjawisk atmosferycznych (zarówno ciagła, jak i skokowa);

${ }^{7}$ A. Szopa, Właściwości ryzyka pogodowego, „Annales Universitatis Mariae Curie-Skłodowska Lublin”, Sectio H, vol. XLVI 1, Lublin 2012, s. 445. 
- trudność prognozowania zjawisk atmosferycznych, a także wysoki koszt instalacji rozbudowanej infrastruktury pomiarowej;

- brak korelacji z innymi kategoriami ryzyka towarzyszacemu prowadzeniu działalności ${ }^{8}$.

\section{PODMIOTY, W KTÓRYCH WYSTĘPUJE RYZYKO POGODOWE}

Zjawiska pogodowe mogą mieć wpływ nie tylko na podaż, ale i na popyt $\mathrm{w}$ danym sektorze. Obie jednak składowe przyczyniają się do obniżenia wartości przychodów ze sprzedaży, a ich pochodną jest zmniejszenie wyniku finansowego i rzeczowego przedsiębiorstwa. W 2002 r. John A. Dutton przeprowadził jedyne, jak do tej pory, badanie wrażliwości PKB Stanów Zjednoczonych na czynniki pogodowe o zasięgu ogólnokrajowym. Oszacowano wtedy, że w 2000 r. wielkość PKB Stanów Zjednoczonych wynosiła 9,87 biliarda dolarów, z czego 3,86 biliarda to część narażona na ryzyko pogodowe. W ujęciu wartościowym więc w tym okresie ponad 38\% amerykańskiego PKB było narażone na ryzyko pogodowe ${ }^{9}$.

Badanie przeprowadzone w 2011 r. przez Jeffreya K. Lazo wykazało, że PKB Stanów Zjednoczonych zmienia się o +/-1,7\% w zależności od zmienności pogody, w przeliczeniu na wartości pieniężne to 485 mld dolarów rocznie ${ }^{10}$.

Warunki pogodowe pośrednio wpływają na funkcjonowanie wielu podmiotów gospodarczych; istnieją jednak takie sektory, na które pogoda ma szczególnie silny wpływ. Do tych sektorów z pewnością należą branża energetyczna, rolnictwo, leśnictwo, budownictwo, turystyka, handel detaliczny, górnictwo, transport - to właśnie te sektory zostały wskazane w badaniu Duttona za najbardziej wrażliwe na pogodę ${ }^{11}$. W dalszej części tego artykułu zostanie przedstawiony wpływ pogody na wybrane sektory gospodarki.

W tabeli 1 zestawiono przykładowe rodzaje ryzyka towarzyszącego poszczególnym branżom oraz podano przykłady ich realizacji.

W sektorze energetycznym kluczową rolę odgrywa temperatura powietrza. Im jest chłodniej, tym większy jest popyt przedsiębiorstw oraz gospodarstw domowych na energię. Przedkłada się to na zwiększoną sprzedaż energii, a także zwiększone zapotrzebowanie zakupu surowców. Analogicznie, kiedy temperatura wzrasta do pewnego poziomu, gospodarstwa domowe i przedsiębiorstwa potrzebują mniej energii na ogrzanie pomieszczeń. Jednakże gdy temperatura stanie się bardzo wysoka, popyt na energię ponownie wzrasta ze względu na wzmożoną eksploatację urządzeń chłodniczych. Według badań prowadzonych przez Juliusza Presia i Pawła Piejaka przychody branży energetycznej moga

\footnotetext{
8 Ibidem, s. 447-448.

${ }^{9}$ M. Harrod et al., Sensitivity of the U.S. Economy to Weather Variability, https://www. aeaweb.org/annual_mtg_papers/2007/0105_0800_0201.pdf [dostęp: 24.12.2015].

10 J. K. Lazo, Economic of weather, „APEC Research Center of Typhoom and Society” 2(4), 2012, s. 27-29.

11 D. Blachowski, op. cit., s. 640.
} 
być zależne od warunków atmosferycznych nawet w $90 \%$. W przypadku Polski wyniki finansowe pojedynczych firm energetycznych mogą odchylać się w granicach 2-6 mln zł w zależności od warunków pogodowych ${ }^{12}$. Nie tylko temperatura ma wpływ na sektor energetyczny. W przypadku produkcji energii ze źródeł odnawialnych prędkość wiatru (elektrownie wiatrowe) oraz opady deszczu (elektrownie wodne) w znaczacy sposób wpływają na sam potencjał produkcyjny. Warto tu zaznaczyć, że część strat poniesionych przez dystrybutorów i producentów energii jest oczywiście przerzucana na odbiorców w postaci zwiększonej ceny. Można więc stwierdzić, że w tym przypadku koszty ryzyka pogodowego ponoszą wszyscy.

\section{Tabela 1}

Związki między pogodą a wynikiem finansowym

\begin{tabular}{|l|l|l|}
\hline \multicolumn{1}{|c|}{ Sektor } & \multicolumn{1}{|c|}{$\begin{array}{c}\text { Rodzaj ryzyka } \\
\text { pogodowego }\end{array}$} & \multicolumn{1}{c|}{ Skutki realizacji ryzyka } \\
\hline Energetyka & Temperatura & $\begin{array}{l}\text { Niższa sprzedaż w okresie zimnego lata } \\
\text { lub ciepłej zimy }\end{array}$ \\
\hline Producenci napojów & Temperatura & Niższa sprzedaż w okresie zimnego lata \\
\hline Hurtownie budowlane & Temperatura/ opady śniegu & $\begin{array}{l}\text { Niższa sprzedaż w okresie ciężkiej zimy } \\
\text { (zamknięte place budowy) }\end{array}$ \\
\hline Budownictwo & Temperatura/ opady śniegu & $\begin{array}{l}\text { Przestoje, opóźnienia w realizacji kon- } \\
\text { traktów }\end{array}$ \\
\hline Stoki narciarskie & Opady śniegu & $\begin{array}{l}\text { Niższe obroty w okresie zimy z opada- } \\
\text { mi poniżej przeciętnych lub większe } \\
\text { koszty naśnieżania stoków }\end{array}$ \\
\hline Rolnictwo & Temperatura/ opady deszczu & Obniżenie wielkości zebranego plonu \\
\hline Władze lokalne & Opady śniegu & $\begin{array}{l}\text { Wyższe koszty poniesione na utrzyma- } \\
\text { nie przejezdności dróg }\end{array}$ \\
\hline Elektrownie wodne & Opady deszczu & Niższe obroty w okresie suszy \\
\hline Transport & Opady śniegu & Opóźnienia w realizacji dostaw \\
\hline Górnictwo & Temperatura & Niższa produkcja w czasie ciepłej zimy \\
\hline
\end{tabular}

Źródło: P. Brockett, M. Wang, C. Yang, Weather derivatives and weather risk management, „Risk Management and Insurance Review" 8(1), 2005, s. 129.

Pochodną zmian wywołanych przez pogodę w sektorze energetycznym sa zmiany w przemyśle górniczym. W Polsce wciąż 90\% wytwarzanej energii pochodzi z węgla ${ }^{13}$. Spadek zapotrzebowania na energię wytwarzaną w tradycyj-

${ }^{12}$ Consus, Ciepto ubezpieczone - derywaty pogodowe dla elektrociepłowni, http://nowa-energia.com.pl/2010/03/30/cieplo-ubezpieczone-\%E2\%80\%93-derywaty-pogodowe-dla-elektrocieplowni/ [dostęp: 24.12.2015].

${ }_{13}$ J. Kania, Przyszłość polskiego węgla jako surowca energetycznego, www.msp.gov.pl/pl-/ przeksztalcenia/serwis-gospodarczy/wiadomosci-gospodarcze/27973,Przyszlosc-polskiego-wegla-jako-surowca-energetycznego.pdf [dostęp: 14.12.2015]. 
ny sposób zmniejsza popyt na surowce pozyskiwane przez górnictwo, a co za tym idzie, zmiany te oddziałują na spadek dochodów kopalń.

Wzrost temperatury w okresie letnim wpływa na większe spożycie napojów, co za tym idzie - wpływa także na wielkość sprzedaży. W Polsce przedsiębiorstwa produkujące napoje zauważyły najwyższą wartość korelacji między temperaturą a sprzedażą napojów w okresie od maja do sierpnia każdego roku ${ }^{14}$.

Rolnictwo ze względu na prowadzenie działalności pod gołym niebem jest szczególnie wystawione na działanie czynników atmosferycznych. Wilgotność, nasłonecznienie, opady śniegu, temperatura, wiatr wpływają na warunki wzrostu roślin, co przekłada się na wielkość zebranego plonu ${ }^{15}$, czyli na skalę produkcji rolnej.

Pogoda ma także wpływ na działalność budowlaną. Przy zbyt niskiej temperaturze i opadach śniegu część robót budowlanych nie może być wcale prowadzona. Przedsiębiorstwa budowlane kierują wtedy swoich pracowników na roboty wykończeniowe wewnątrz budynków albo też są zmuszone nawet do redukcji zatrudnienia. Przedłużająca się niepogoda może prowadzić do opóźnień w pracach, które to z kolei moga być obwarowane karami umownymi. Przynosi to więc wymierne straty dla sektora budowlanego. W przypadku innych czynników atmosferycznych istotna przeszkodę stanowią także opady deszczu, które utrudniają prowadzenie robót dekarskich oraz elewacyjnych. Silny wiatr zakłóca pracę na wysokości z użyciem żurawi, a zbyt wysoka temperatura nie tylko przeszkadza w niektórych pracach (np. wylewka betonu), ale i wpływa na efektywność pracy.

Branża turystyczna jest niewątpliwie narażona na negatywne warunki atmosferyczne. Przedsiębiorstwa z branży turystycznej wypracowały rozwiązania, które pomagają im rozwiązać chwilowe kaprysy pogody. W kurortach można znaleźć kryte baseny, „klimatyczne” restauracje, parki rozrywki oraz szereg innych atrakcji, a w przypadku braku śniegu na stoku - zostaje on zastapiony sztucznym. Sytuacja, w której niekorzystne warunki pogodowe utrzymują się przez dłuższy okres, wywołuje jednak znaczne straty dla sektora turystycznego. Niekorzystne prognozy pogody moga spowodować odwoływanie rezerwacji przez klientów. Jako przykład niekorzystnego wpływu pogody na turystykę można podać początek lata 2006 r. we Włoszech. Był to okres silnych opadów deszczowych. Weneccy hotelarze w obawie przed odwołaniem rezerwacji obiecywali klientom, że zwolnią ich z opłaty za nocleg, jeśli nieprzerwane opady deszczu potrwają dłużej niż 5 godzin w ciagu dnia ${ }^{16}$.

Istnieją także przedsiębiorstwa działające sezonowo, gdzie głównym czynnikiem kreujaccym popyt na ich usługi są warunki pogodowe. Są to np. przed-

14 J. Pawłowski, Pogodowe instrumenty pochodne - możliwości zawarcia transakcji na przykładzie producentów wody butelkowej w Polsce, „Acta Universitatis Lodziensis Folia Oeconomica” 2(301), 2014, s. 208.

15 E. Stroiński, Ubezpieczenia majatkowe i osobowe $w$ rolnictwie, Wyd. AF, Warszawa 2006, s. 31 .

16 D. Michalak, op. cit., s. 46-47. 
siębiorstwa zajmujące się odśnieżaniem dróg i dachów. W przypadku braku opadów śniegu popyt na odśnieżanie spada do zera, a przedsiębiorstwa nie generują dochodów (jeśli zawierają umowy o wykonanie dzieła, inaczej jest gdy umowy mają charakter abonamentowy). Z drugiej strony opady śniegu powodują dodatkowe koszty chociażby dla podmiotów zobowiązanych do utrzymania przejezdności dróg (mowa tu np. o władzach lokalnych).

Wymienione powyżej przykłady branż i sektorów wrażliwych na warunki pogodowe stanowią katalog otwarty podmiotów wrażliwych na działanie czynników pogodowych.

\section{OPCJE POGODOWE}

Ochronę przed ryzykiem pogodowym mogą stanowić instrumenty pochodne przeciwdziałające negatywnym skutkom jego występowania. Pierwszy przypadek wykorzystania instrumentów pochodnych opartych na indeksie meteorologicznym odnotowano w Stanach Zjednoczonych w $1996 \mathrm{r}$. W tym czasie nastapiła deregulacja amerykańskiego rynku energii. Konkurujące ze soba przedsiębiorstwa zaczęły zwracać większą uwagę na proces zarządzania ryzykiem, w tym także ryzykiem pogodowym. Uświadomiły sobie, jak znaczny jest wpływ pogody na ich funkcjonowanie oraz uzyskiwane wyniki. Pierwsza zawartą umową pogodową była umowa pomiędzy Aquila Inc a Consolidated Edison Inc ${ }^{17}$. Dotyczyła ona ochrony przed niską temperatura w sierpniu 1996 r.; jako bazę wykorzystano tu indeks $\mathrm{HDD}^{18}$. Inne źródła podają jednak, że pierwszą transakcję derywatami pogodowymi stanowił kontrakt między Koch Industry a Enronem. Kontrakt był także oparty na indeksie temperatury powietrza HDD, a dotyczył okresu zimowego na przełomie 1997 i 1998 r. w Milwaukee ${ }^{19}$. Kontrakt między Koch Industry a Enronem jest uważany przez część badaczy za pierwszy, dlatego że posiadał przejrzyście ustalony sposób wyceny oraz został on podany do publicznej wiadomości, cech tych brakowało kontraktowi pomiędzy Aquila Inc a Consolidated Edison $\mathrm{Inc}^{20}$.

Obecnie na rynku terminowych kontraktów pogodowych występuje pięć rodzajów kontraktów pogodowych. Kontrakty te występują także w obrocie publicznym; jako pierwsze derywaty pogodowe zadebiutowały na Chicago Mercantile Exchange (CME) w 1999 r. ${ }^{21}$ Rodzaje terminowych kontraktów pogodowych zostały zaprezentowane na schemacie 2 .

\footnotetext{
${ }^{17}$ M. Nicholls, Confounding the forecasts, „Environmental Finance” 6(1), 2004, s. 22-23.

${ }^{18} \mathrm{HDD}$ - heating degree day, indeks pogodowy oparty na przeciętnej temperaturze danego dnia, konstruowany na z góry założoną liczbę dni.

${ }^{19}$ P. Prewysz-Kwitno, Gietdowe derywaty pogodowe, „Zeszyty Naukowe Uniwersytetu Szczecińskiego" nr 768, Finanse, Rynki Finansowe, Ubezpieczenia nr 63, Szczecin 2013, s. 422.

${ }^{20}$ J. Preś, Zarzqdzanie ryzykiem pogodowym, CeDeWu, Warszawa 2007, s. 75-76.

${ }^{21}$ Ibidem, s. 77.
} 


\section{Schemat 2}

Rodzaje terminowych kontraktów pogodowych

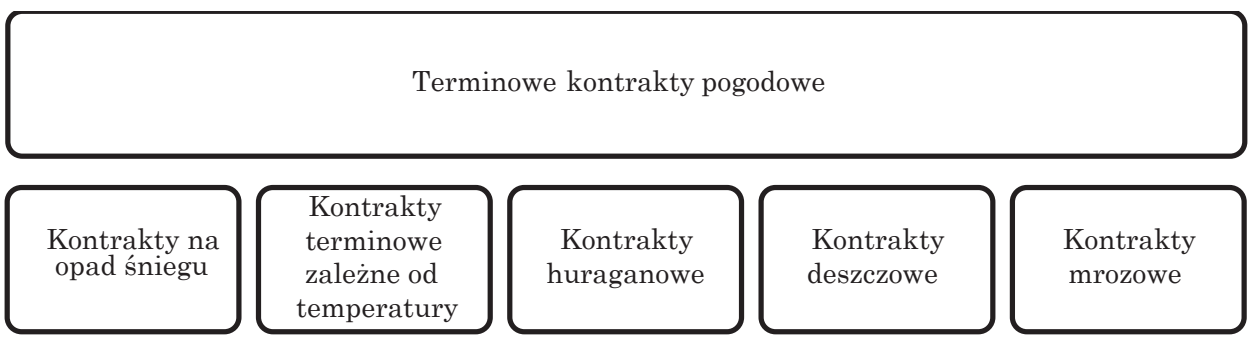

Źródło: K. Prus, Ł. Świerszcz, Pochodne instrumenty kredytowe, instrumenty pogodowe i katastroficzne, prezentacja niepublikowana, Uniwersytet Warszawski 2013.

Kontrakty na opad śniegu są wypłacane za każdą jednostkę opadów śniegu powyżej lub poniżej wartości określonej w kontrakcie. Wielkość stawki jednostkowej w przypadku standaryzowanego kontraktu, którego obrót odbywa się na giełdzie, jest uzależniona od lokalizacji. Aby instrument ten mógł poprawnie funkcjonować, konieczne jest skonstruowanie indeksu opartego na wysokości opadów. W Stanach Zjednoczonych konstruowane sa takie indeksy dla wybranych regionów. Największe zainteresowanie na rynku w przypadku kontraktów na opady śniegu występuje w okresie od września do grudnia. Zainteresowane nabyciem tego kontraktu mogą być służby miejskie, przedsiębiorstwa zajmujące się odśnieżaniem, producenci soli drogowej czy kurorty narciarskie. Na rynku amerykańskim kontrakty na opady śniegu sa oferowane od 2006 r.; pierwotnie były one skierowane właśnie do władz lokalnych jako narzędzie wspomagające proces zarządzania ryzykiem.

Obecnie wykształciły się dwa modele kontraktów śnieżnych. Pierwszy pay for push polega na tym, że nabywca opcji (np. firma odśnieżająca, producent soli drogowej) nalicza opłatę w zależności od wystapienia pewnych określonych okoliczności (zazwyczaj jest to uzależnione od liczby interwencji). W drugim modelu - all inclusive nabywcą opcji jest klient, który ponosi stała opłatę za cały sezon. W przypadku srogiej zimy klient oszczędza (gdyż zawarł kontrakt na stała kwotę), a w okresie lekkiej zimy korzyści z kontraktu odnosi firma odśnieżająca, która zabezpieczyła źródło dochodów dzięki odpowiedniej ilości zawartych kontraktów. Aby zabezpieczyć się przed zwiększonymi kosztami w okresie srogiej zimy, firmy odśnieżające moga zawrzeć przeciwstawny kontrakt opcyjny all inclusive z reasekuratorem ${ }^{22}$.

W przypadku kontraktów zależnych od wysokości temperatury - istnieje kilka wskaźników, które moga być wykorzystane jako instrument bazowy. W Stanach Zjednoczonych i Kanadzie wykorzystuje się wskaźnik HDD (heat-

${ }^{22}$ K. Prus, Ł. Świerszcz, Pochodne instrumenty kredytowe, instrumenty pogodowe $i$ katastroficzne, prezentacja niepublikowana, Uniwersytet Warszawski 2013. 
ing degree day) ${ }^{23} \mathrm{w}$ zimie oraz $\mathrm{CDD}^{24}$ (cooling degree day) $\mathrm{w}$ lecie, natomiast w Europie stosuje się wskaźnik CAT (cumulative average temperature - alternatywa dla HDD oraz CDD, to indeks przedstawiający średnią dzienną temperaturę powietrza).

Kontrakty na indeks temperatury można zawrzeć w zasadzie na dowolnie wybrany okres, najpopularniejsze są okresy tygodniowe, miesięczne oraz sezonowe (na sezon letni/zimowy). Ciekawym przykładem wykorzystania instrumentu pochodnego opartego na indeksie temperatury jest zastosowanie go w sieci londyńskich winiarni Corney \& Barrow. Winiarze zauważyli zwiększone obroty w tych dniach, w których temperatura przekraczała $24^{\circ} \mathrm{C}$. Aby ochronić się przed stratami wywołanymi niższą temperatura, w 2000 r. zakupili instrument pochodny, który zapewniał im finansową rekompensatę, gdy w letnie czwartki i piątki temperatura nie przekraczała $24^{\circ} \mathrm{C}$. Im niższa była odnotowana temperatura, tym wyższa była kwota wypłacana dla winiarni (szacuje się, że wynosiła ok. 1500 funtów dziennie). Po drugiej stronie kontraktu stała nieistniejąca już dziś firma energetyczna Enron (transakcja była oparta na bazie opcji put wystawionej przez Enron) ${ }^{25}$.

Kontrakty terminowe oparte na indeksie pogodowym zostały także dopuszczone do publicznego obrotu. Jako pierwsza kontrakty terminowe oparte na indeksie temperatury wprowadziła do obrotu giełdowego Chicago Mercantile Exchange (CME) w $1999 \mathrm{r} .{ }^{26}$ Był to kontrakt oparty na indeksach HDD i CDD dla 10 amerykańskich miast.

Obecnie CME oferuje pogodowe instrumenty pochodne oparte na indeksach: temperatury, opadu deszczu, śniegu, liczby dni mroźnych oraz indeksu ukazującego siłę huraganów, które nawiedzają Stany Zjednoczone ${ }^{27}$.

Jako przykład wykorzystania kontraktu huraganowego może posłużyć opcja notowana na CME. Oparta jest ona na indeksie Carvill Hurricane i służy do zabezpieczenia się przed stratami spowodowanymi przez drugi huragan w tym samym roku. Opcja ta ma stwarzać możliwość zabezpieczenia się podmiotom, które wykorzystały już instrumenty zabezpieczające przed ryzykiem katastroficznym (np. ubezpieczenie), a dany region powtórnie został nawiedzony przez huragan ${ }^{28}$. Kontrakt ten jest związany ze zjawiskiem o charakterze katastroficznym, co odróżnia go od pozostałych omawianych kontraktów, niemniej pominięcie go w rozważaniach spowodowałoby wystapienie luki w analizowanych kontraktach pogodowych dopuszczonych do obrotu.

${ }^{23}$ HDD - wskaźnik ten jest nazywany „stopniodniem ogrzewania”. To miara ilościowa, stworzona przez inżynierów ciepłownictwa, oznacza zapotrzebowanie na energię do ogrzania budynku. Temperatura bazowa wynosi $18^{\circ} \mathrm{C}$, a indeks ten jest wyznaczany w okresie od września do kwietnia.

${ }^{24}$ CDD - analogicznie do HDD wskaźnik ten wyznacza zapotrzebowanie na energię do klimatyzacji budynku.

25 S. Winiecki, Ile kosztuje deszcz? Wstep do pogodowych instrumentów pochodnych, „Equity Magazine" z 6 listopada 2010 r., s. 21.

\footnotetext{
26 J. Preś, op. cit., s. 77.

27 P. Prewysz-Kwitno, op. cit., s. 422.

${ }^{28}$ K. Prus, Ł. Świerszcz, op. cit.
} 
Kontrakty mrozowe są wykorzystywane m.in. przez przedsiębiorstwa budowlane do zabezpieczenia przed stratami zatrzymania prac w wyniku zbyt niskich temperatur. Jest to kolejny z kontraktów wprowadzonych do publicznego obrotu na $\mathrm{CME}^{29}$. Jego podstawą jest liczba dni mroźnych występujących w okresie od pierwszego poniedziałku w listopadzie do ostatniego piątku $\mathrm{w}$ marcu ${ }^{30}$. Kontrakt ten został skonstruowany na potrzeby holenderskiego rynku budowlanego. Okres naliczania indeksu obejmuje czas, w którym najczęściej występuje mróz, ale wyłącza on te dni, które są wolne od pracy dla holenderskich pracowników budowlanych ${ }^{31}$. Za dzień mroźny uznaje się ten, w którym został spełniony co najmniej 1 z 3 poniższych warunków:

- temperatura o godzinie 7.00 była niższa bądź równa $-3,5^{\circ} \mathrm{C}$;

- temperatura o godzinie 10.00 była niższa bądź równa $-1,5^{\circ} \mathrm{C}$;

- pomiary temperatury dla godziny 7.00 oraz 10.00 były niższe niż $-0,5^{\circ} \mathrm{C}$.

Co ciekawe, mimo że instrument ten jest dostosowany do potrzeb holenderskiego rynku (pomiary dokonywane sa jedynie dla Amsterdamu), jest on notowany na giełdzie w Chicago. Jednostkowa zmiana kontraktu opartego na indeksie Frost wynosi 10000 euro $^{32}$.

Instrumenty pochodne oparte na indeksie deszczu należa do najmłodszych derywatów pogodowych wprowadzonych na CME. Obecnie skonstruowane są jako średnia miesięczna ilość opadu (w calach) dla 10 miast w Stanach Zjednoczonych. Każdy punkt indeksowy (cal deszczu) jest wart 500 dolarów. Kontrakty deszczowe dostępne są w dwóch wariantach. Pierwszy obejmuje okres jednego wybranego miesiacca, spośród okresu od marca do października. Drugi pozwala na wybór co najmniej dwóch kolejnych miesięcy $\mathrm{z}$ analogicznego okresu ${ }^{33}$. Według giełdy chicagowskiej największe zainteresowanie kontraktami deszczowymi występuje wśród producentów i dystrybutorów energii, przedsiębiorstw użyteczności publicznej, organizatorów imprez sportowych i koncertów, parków tematycznych i innych podmiotów, których funkcjonowanie jest zależne w znacznej mierze od zmienności tego czynnika ${ }^{34}$.

\section{PODSUMOWANIE}

W ostatnich latach ryzyko pogodowe stało się bardzo ważną kategoria dla wielu przedsiębiorstw, mimo że pogoda oddziaływała na funkcjonowanie przedsiębiorstw od zawsze. Obecnie szacuje się, że pogoda ma pośredni lub bezpośredni wpływ na funkcjonowanie ponad $70 \%$ przedsiębiorstw na świecie. Sektorami najbardziej wrażliwymi na zmiany warunków atmosferycznych sa energetyka, rolnictwo, turystyka oraz budownictwo.

${ }^{29}$ Został on wprowadzony na CME w 2005 r.

${ }^{30}$ Do tego okresu nie wlicza się sobót, niedziel oraz 25 grudnia, 26 grudnia i 1 stycznia.

31 J. Groningen, Weather Derivatives as a Hedging Tool for Construction Firms, http://arno. uvt.nl/show.cgi?fid-=129768 [dostęp: 24.12.2015].

32 P. Prewysz-Kwitno, op. cit., s. 431.

33 Ibidem, s. 430-431.

${ }^{34}$ K. Prus, Ł. Świerszcz, op. cit. 
Aby przeciwdziałać negatywnym skutkom realizacji ryzyka pogodowego, można wykorzystać instrumenty pochodne oparte na indeksie pogodowym, w tym opcję pogodową. Rynek derywatów pogodowych rozwija się dynamicznie. Pogodowe instrumenty pochodne funkcjonują zarówno na rynku pozagiełdowym (np. kontrakt między londyńską winiarnią a Enronem), jak i giełdowym (występujące kontrakty pogodowe na giełdzie w Chicago) ${ }^{35}$.

Mimo że opcja pogodowa istnieje już prawie 20 lat, jak dotąd nie odnotowano jeszcze przypadku wykorzystania tego instrumentu w Polsce (opartego na wskaźniku wyznaczonym dla lokalizacji mającej miejsce w Polsce). Nie oznacza to jednak, że w Polsce nie można zakupić derywatów pogodowych, co prawda zakup tych instrumentów przez osoby fizyczne jest utrudniony (np. zakup kontraktu forward o ekspozycji wynoszącej minimum 250000 euro, znacznie przekracza możliwości przeciętnego inwestora), ale inwestorzy instytucjonalni moga korzystać z platform transakcyjnych działajacych w nawiązaniu do rynku OCT lub też powiązanych z giełdą CME. Funkcjonujacy w Polsce dom maklerski Consus deklaruje, że planuje w przyszłości stworzyć w Polsce rynek kontraktów pozwalających handlować instrumentami pogodowymi podobnie, jak dziśs odbywa się obrót na kontraktach WIG $20^{36}$. Niewykluczone, że w przyszłości mogą także powstawać indeksy pogodowe chroniące interesy polskich przedsiębiorstw. Upływ czasu oraz dalsze kierunki rozwoju rynku instrumentów pochodnych pokażą, czy znajdzie się na nim miejsce dla derywatów pogodowych.

mgr Zuzanna Czekaj

Uniwersytet Ekonomiczny w Poznaniu

zuzanna.czekaj@ue.poznan.pl

\title{
WEATHER DERIVATIVES AS AN INSTRUMENT \\ OF WEATHER RISK MANAGEMENT
}

Sum mary

\begin{abstract}
Weather risk has an increasing impact on the functioning of today's enterprises. To manage weather risk effectively companies may use weather derivatives. This article attempts to classify entities that could be used as part of weather risk management derivatives, especially weather derivatives. At the outset it presents the essence of weather risk, defining and classifying this phenomenon. This is followed by a description of those entities on which the weather has a significant effect. Next weather derivatives are presented, starting with the construction of the instrument, through the history of weather derivatives on the world market, and ending with a reflection on the applicability of weather derivatives in a Polish context.
\end{abstract}

${ }_{35}^{35}$ P. Prewysz-Kwitno, op. cit., s. 421.

${ }^{36}$ P. Zając, Czy można zarabiać na pogodzie? Meteorolodzy na giełdę!, http://analizy.investio. pl/czy-mozna-zarabiac-na-pogodzie-meteorolodzy-na-gielde/ [dostęp: 24.12.2015]. 